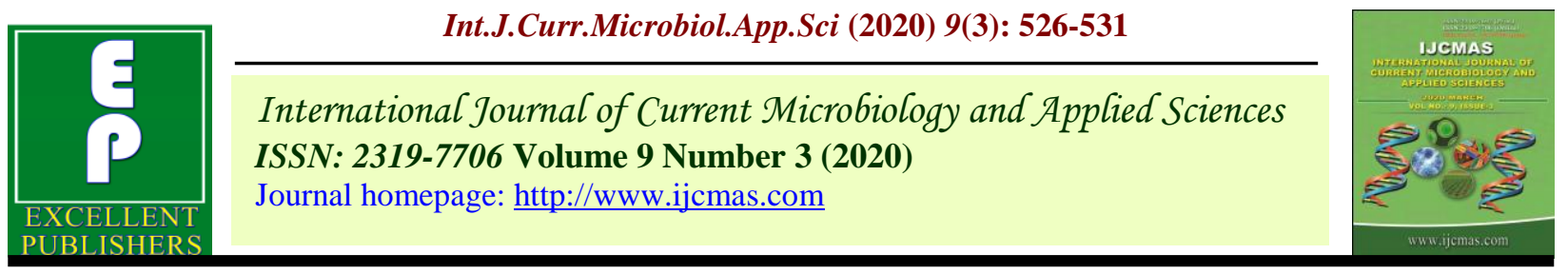

Original Research Article

https://doi.org/10.20546/ijcmas.2020.903.061

\title{
A Comparative Study of Different Carriers for Shelflife of Rhizobium spp.as Bioinoculants
}

\author{
Premlata Kumari ${ }^{1 *}$ and Poonam Sharma ${ }^{2}$ \\ ${ }^{1}$ Department of Microbiology, Punjab Agricultural University, Ludhiana, Punjab, India \\ ${ }^{2}$ Department of Plant Breeding and Genetics, Punjab Agricultural University, \\ Ludhiana, Punjab, India \\ *Corresponding author
}

Keywords

charcoal, mushroom compost,

vermicompost

Article Info

Accepted:

05 February 2020

Available Online:

10 March 2020

\section{A B S T R A C T}

In the present investigation three carriers, charcoal, mushroom compost, vermicompost were evaluated for the production of bioinoculants. The bacteria used for bioinoculants development was recommended Rhizobium spp. (M1). The Rhizobium strains were inoculated in all the three carriers singly and in combination with different carriers. The bacterial population was determined in each carrier up to 3 monthsof storage. The mushroom compost show the highest bacterial population and and bacterial population was uniform throughout the months of storage, whereas after 15 days of incubation the bacterial population in vermicompost was increased and decreased in the charcoal. Considering these results, the mushroom compost as carrier could increase the survival of bacteria and might be as a bioinoculants.

\section{Introduction}

Application of biofertilizer for crop production is environmental friendly and sustainable for ecological system. Biofertilizer are low cost, effective and renewable source of plant nutrients to supplement chemical fertilizers (Boraste et al., 2009). Biofertilizer consists of carriers and the microorganisms (Shariati et al., 2013). Several types of biofertilizer have been developed from bacteria, particularly
Rhizobium spp., Azospirillum spp., and Azotobacterspp., and used in production of various plants (Mala, 2003; Narula, 2000; Rai, 2006). These beneficial organisms are applied in the form of microbial inoculants (Karunai et al., 2013).

The inoculants can be prepared from several types of carriers such as peat, charcoal, farm yard manure, lignite, alginate, etc., Nowadays; several types of agricultural waste like maize stubble, plant compost, mushroom 
waste, rice straw, oil palm and bunch can be composted and used as bio inoculant carrier. This system helps reducing the pollutants, saving energy, decreasing cost of production, and utilizing natural resources to the benefit (Phiromtan et al., 2013).

Earthworm's vermicompost give very high food productivity comparable to or even better than the chemical fertilizers with significantly higher nutritional quality which also improving the physical, chemical and biological properties of soil. Vermicomposting is highly nutritive and a powerful plant growth promoter and protector and has scientifically proven to be a miracle plant growth promoters.

Vermicompost is a uniform and odourless material with good physical structure, abundant labile resources and high microbial activity (Pramanik et al., 2007;Ngo et al., 2011). It contains larger quantities of mineral and trace elements than traditional compost which are available for plant uptake (Tejada et al., 2009; Arancon and Edwards, 2011). It also contains plant growth regulating substances such as auxins, gibberellins, cytokinins, fulvic and humic acids which are beneficial for plant performance (Zhang et al., 2014). Spent mushroom substrate (SMS) has good physical properties; it includes the water holding capacity, soil $\mathrm{pH}$, soil porosity, salt content i.e electrical conductivity. Addition of SMS will add great amount of macro nutrients (Kim et al., 2011). The biological properties of SMS enhance its marketability as a soil conditioner (Brady and Wiel, 2004).

Spent compost is believed to be a source of humus formation and humus is provided to the plants with micronutrients improve the soil aeration, soil water holding Capacity and contributes the maintenance of soil structure (Kediri and Mustapha, 2010). By considering all good properties of mushroom compost, it has been tested in the present study to use it as carrier for shelf life of Rhizobium spp. and compared with other carriers like charcoal and vermicompost.

\section{Materials and Methods}

\section{Preparation of carriers}

Charcoal, mushroom compost and vermicompost were used in this study. The raw material were ground, sieved with $0.5 \mathrm{~cm}$ mesh screen and dried in a hot air oven at $60^{\circ} \mathrm{C}$ for two days. The materials were autoclave at $121^{\circ} \mathrm{C}$ at a pressure of $15 \mathrm{lb}$ for 30 minutes for two successive days.

\section{Treatments}

$\mathrm{T} 1=$ Charcoal

$\mathrm{T} 2=$ Vermicompost

T3=Mushroom compost

T4=Charcoal+vermicompost

T5=Charcoal+mushroom compost

T6=Vermicompost+mushroomcompost

$\mathrm{T} 7=$ Charcoal+vermicompost+mushroom compost

\section{Procurement and preparation of bacterial inoculants}

Recommended native isolates of Rhizobium spp. (M1) were obtained from the Pulses section, Department of Plant Breeding and Genetics, for the use in present study. The medium used for Rhizobium (M1) was Yeast Extract Mannitol (YEM) broth sterilized by autoclaving at $121^{\circ} \mathrm{C}$ at a pressure of $15 \mathrm{lb}$ for 30 minutes. After sterilization the medium was kept at room temperature followed by inoculation with a loopful of Rhizobium culture from agar slant under aseptic conditions and kept in rotary shaker for $48 \mathrm{hr}$ at $28^{\circ} \mathrm{C}$. After incubation, $10 \mathrm{ml}$ of the inoculums was transferred to $1000 \mathrm{ml}$ of respective broth and kept in shaking incubator 
for mass multiplication.750 $\mathrm{ml}$ was mixed thoroughly with $1000 \mathrm{~g}$ of each sterile carrier, packed in polyethylene bags, sealed and incubated for 7 days at $28 \pm 1^{0} \mathrm{C}$. For studying the shelf life of Rhizobium the packets was stored at $4^{0} \mathrm{C}$ temperatures.

\section{Evaluation for shelf life of the Rhizobium sp. during storage}

The shelf life of Rhizobium sp. was determined after the inoculums were subjected to different carriers. One grams of each sample was taken for estimating viable cells at every 15 days up to 3 months using dilution plating method on Yeast Extract Mannitol Agar (YEMA) and incubated at $28^{\circ}$ $\mathrm{C}$ for 2 days. The number of apparent Rhizobium colonies after incubation from different treatments was counted and calculated into viable cells.

\section{Counting colonies of Rhizobium spp. (M1)}

The number of colonies were counted from YEMA plates after the incubation peroid of $48 \mathrm{hrs}$ as colony forming units (cfu) per $\mathrm{ml}$ and expressed as cfu per gram of carrier material. The plate count was carried out in triplicates and final value of cfu was the average of three readings and converting cfu into $\log \mathrm{cfu} / \mathrm{gm}$ of carrier by using following formula:

$$
\log \left(a \times b^{n}\right)=\log a+n \log b
$$

Where

$\mathrm{a}=$ Mean number of bacterial colonies

$\mathrm{b}^{\mathrm{n}}=$ Dilution factor

\section{Results and Discussion}

In the present study, the shelf life of Rhizobium sp. as bio inoculants was studied in different carrier based culture packets. The population of bacteria was determined by measuring the log cfu/gm up to 3 months.

The data presented in Table 1 indicates the surviablity of Rhizobium in different carrier up to 3 months. Among all the tested carrier material, mushroom compost was found to best carrier among all the carrier materials and supported the significantly highest bacterial count $10.85 \mathrm{log} \mathrm{cfu} / \mathrm{gm}$ of carrier material after 3 months of storage and it was found significantly superior over all other combination at 90 days., whereas after 15 days of incubation the bacterial population in the charcoal was intensively declined and it was maintained at $5.1 \log \mathrm{cfu} / \mathrm{gm}$ after 3 months of storage (Fig.1). While the population of bacteria in the vermicompost increased after 15 days and observed maximum $10.54 \log \mathrm{cfu} / \mathrm{gm}$ of carrier at 90 days. So, mushroom compost found to be a good carrier for shelf life and might be used as bio inoculants. This may be due to more water holding capacity of carrier material.

These findings are correlated with Shitole et al., (2014) who reported that spent mushroom substrate showed good carrier for shelf life and survival of $T$. viride $(2 \times 106 \mathrm{cfu} / \mathrm{g})$ and Rhizobium (20.66x108cfu/g) at 180 days as compared to other carrier combination. Similarly Rebah et al., (2007) reported that some industrial and agricultural by-products (e.g. cheese whey, malt sprouts)contain growth factors such as nitrogen and carbon whichcan support growth of rhizobia. Other agro-industrial wastes (e.g. plant compost, filterter mud and fly-ash) can be used as a carrier for Rhizobial inoculant. More recently, waste water sludge a worldwide recyclable waste has shown good potential for inoculant production as a growth medium and as a carrier (dehydrated sludge). 
Table.1 Population density (log cfu/gm) of Rhizobium of in different carriers

\begin{tabular}{|c|c|c|c|c|c|c|c|}
\hline Treatments & 0 days & $\mathbf{1 5}$ days & 30 days & 45days & 60days & $\mathbf{7 5}$ days & 90days \\
\hline T1 & 9.43 & 9.59 & 9.28 & 8.42 & 7.39 & 7.24 & 5.21 \\
\hline T2 & 8.77 & 8.85 & 9.45 & 9.98 & 10.02 & 10.44 & 10.54 \\
\hline T3 & 9.67 & 9.92 & 10.03 & 10.33 & 10.67 & 10.78 & 10.85 \\
\hline T4 & 8.23 & 8.72 & 8.84 & 8.57 & 7.83 & 7.71 & 7.69 \\
\hline T5 & 8.12 & 8.69 & 8.95 & 8.79 & 8.60 & 8.54 & 8.32 \\
\hline T6 & 9.02 & 8.83 & 8.90 & 8.71 & 8.64 & 8.57 & 8.40 \\
\hline T7 & 9.28 & 8.97 & 8.76 & 8.64 & 8.84 & 8.65 & 8.14 \\
\hline C D (5\%) & \multicolumn{7}{|c|}{ Inoculants: 0.58 storage period: 0.58 Ix S: NS } \\
\hline
\end{tabular}

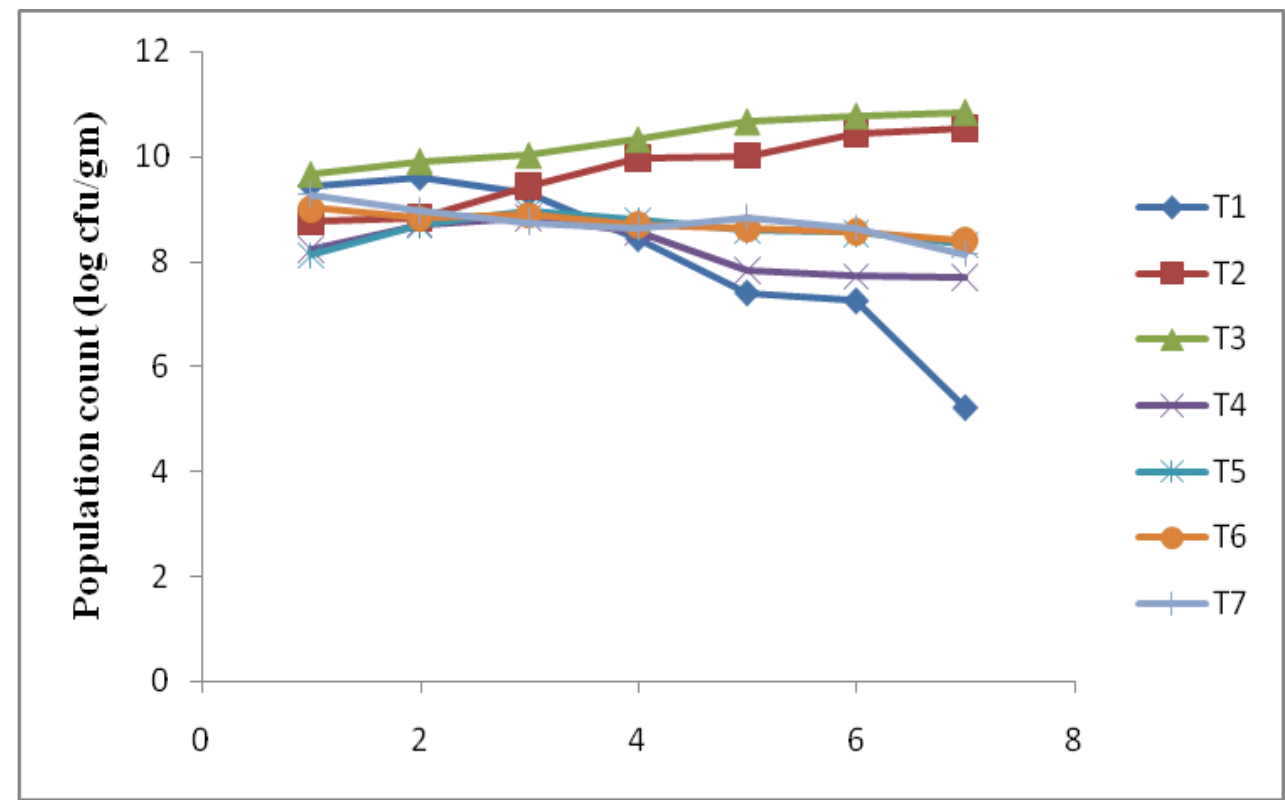

Fig. 1: Population density (log cfu/gm) of Rhizobium (M1) spp. in different carrier materials

Sekar and Karmegam (2010)reported that vermicasts from E.euginiaeas a carrier materialwhich supports the survival of more than $1 \times 107 \mathrm{~g}-1$ viable cell of A.chroococum, B.megaterium and $R$. leguminosarum till the end of 10th month which is longer than observed in lignite. Chao and Alexander (1984) concluded that bacterial retention on activated charcoal and peat carrier at $25^{\circ} \mathrm{C}$ was more than $4^{0} \mathrm{C}$. Mendez and Videira (2005) stated that bacterial maintenance at 28 ${ }^{0} \mathrm{C}$ for 41 days caused an increase in number of viable bacterial cells on all carriers so that the population reached nearly $10^{9}$ bacteria per gram of carrier.
Use of organic sources of fertilizers improved the soil chemical properties through increasing the content of macro and micronutrients and organic carbon. This study recommended the mushroom compost as a carrier material because mushroom compost supported good survival of Rhizobium count.

\section{References}

Arancon NQ, Edwards C A (2011)The use of vermicomposts as soil amendments for production of field crops. In: Edwards, C.A., Arancon, N.Q., Sherman, R.L. (Eds.), Vermiculture Technology: 
Earthworms, Organic Wastes, and Environmental Management. CRC Press, Boca Raton, pp. 129-151.

Boraste A, Vamsi KK, Jhadav A, Khairnar Y, Gupta N, Trivedi S, Patil P, Gupta G , Gupta M, Mujapara AK, Joshi B (2009) Biofertilizers: A novel tool for agricultural 1(2):23-31.

Brady N and Wiel R( 2004) Elements of the nature and properties of soils Pearson Education Inc. New Jersey. PublisherPrentice Hall, On-line Supplement. p.144.

Chao WL, and Alexander M (1984) Inoculants mineral soils as carriers for Rhizobium. Appl environ microbial, 47(1):94-97.

Kadiri and Mustapha (2010) The use of spent mushroom substrate of Agarics bisporus as a soil conditioner for vegetables. $J$. Ind. Soc. Soil. Sci.40(1): 518-519.

Karunai S B (2013) Preparation of phosphate solubilising microbial inoculants using vermicompost as a carrier material. Research Journal of pharmaceutical, Biological and chemical sciences4(2):146-149.

Kim Y L, Cho W M, Hong S K, Oh Y K and Kwak W S (2011) Yield Nutrient characteristics, Ruminal Solubility and Degradability of Spent mushroom (Agaricusbisporus) substrate for Ruminants. Asian- Aust. J. Anim. Sci.24(11): 1560-1560.

Mala T (2003). Organic Fertilizer and Biofertilizer: Production Techniques and Usage. Bangkok, Thailand: Kasetsart University Press.

Mendes F, Videira I (2005) Residues of the cork industry as carriers for the production of legume inoculants; 2780159

Narula N (2000) Azotobacter in Sustainable Agriculture. New Delhi, India: CBS Publishers and Distributors.

Ngo P T, Rumpel C, Doan T T, Jouquet P
(2012) The effect of earthworms on carbon storage and soil organic matter composition in tropical soil amended with compost and vermicompost. Soil Biol. Biochem. 50: 214-220.

Phiromtan M, Mala T and Srinives P(2013) Effect of various carriers and storage temperatures on survival of AzotobactervinelandiiNDD-CK-1 in powder inoculants. Modern Applied science 7(6):81-89.

Pramanik P, Ghosh G, Ghosal P, Banik P (2007) Changes in organic - C N, P and $\mathrm{K}$ and enzyme activities in vermicompost of biodegradable organic wastes under liming and microbial inoculants. Bioresour. Technol. 98: 2485-2494.

Rai M K (2006) Handbook of microbial biofertilizers. New York, USA: Food Products Press, Binghamton.

Raja Sekar K, and Karmegam N (2010)Earthworm casts as an alternate carrier material for biofertilizers: assessment of endurance and viability of Azotobacter chroococcum, Bacillus megaterium and Rhizobium leguminosarum.ScientiaHorticulturae 12 4(2):286-289.

Rebah F B, Prévost D, Yezza A and Tyagi R D (2007) Agroindustrial waste materials and wastewater sludge for rhizobial inoculant production: A review. Bioresource Technol. 98: 3535-3546.

Shariati S, Alikhani H A, PourbabaeiA(2013) Application of vermicompost as a carrier of phosphate solubilising bacteria in increase growth parameters of maize. Int. J Agronomy and plant production4(8):2010-2017.

Shitole A V, Gade R M, Bandgar M S., Wavare S H and Belkar Y K (2014) Utilization of spent mushroom substrate as carrier for biocontrol agent and biofertilizer. The Bioscan9(1): 271-275.

Tejada M, García-Martínez A, Parrado J 
(2009). Effects of a vermicompost composted with beet vinasse on soil properties, soil losses and soil restoration. Catena 77:238-247.

Zhang H, Tan SN, Wong WS, Ng CYL, Teo
CH, Ge L, Yong JWH (2014) Mass spectrometric evidence for the occurrence of plant growth promoting cytokinins in vermicompost tea. Biol. Fertil. Soils50: 401-403.

\section{How to cite this article:}

Premlata Kumari and Poonam Sharma. 2020. A Comparative Study of Different Carriers for Shelflife of Rhizobium spp.as Bioinoculants. Int.J.Curr.Microbiol.App.Sci. 9(03): 526-531. doi: https://doi.org/10.20546/ijcmas.2020.903.061 